\title{
Pengaruh Jenis Larutan Osmotik pada Invigorasi Benih Kakao (Theobroma cacao L.) dengan Beberapa Lama Pengeringan
}

The Effect of Osmotic Solution Type on Cocoa (Theobroma cacao L.) Seed Invigoration with Several Long of Drying

\section{Sri Lestari Hutabarat, Haryati*, Irsal}

Program Studi Agroteknologi, Fakultas Pertanian, USU, Medan 20155

*Corresponding author: atie.koto@yahoo.co.id

\section{ABSTRACT}

This study aims to determine the effect of osmotic solution on cocoa (Theobroma cacao L.) seed invigoration with several long drying. This research was conducted at Laboratory of Seed Technology, Faculty of Agriculture, University of Sumatera Utara, from August to September 2016, using a randomized block design with 2 treatment factors. The first factor is a type of solution ie without immersion; aquades; coconut water 50\%; coconut water 100\%; Polyethylene Glykol (PEG) 6000 5\%; PEG $600010 \%$ and the second factor is long drying with 4 levels ie 1 day; 2 days ; 3 days ; 4 days. The results showed that the best treatment of osmotic solution was found in treatment of coconut water with 50\% concentration which resulted in germination rate of 5.51 days and vigor index of 3.79. The best long of drying treatment was 1 day drying with average germination potential $99.17 \%$, germination rate 4.46 days, normal germination $93.06 \%$, abnormal germination, $12.21 \%, 5.35 \%$ dead seed and vigor index 5,34. The best treatment interaction on the combination of treatment type of osmotic solution of PEG $60005 \%$ with 1 day drying time resulted in vigor index of 6.80 .

Keywords: cocoa seed, invigoration, long drying, osmotic solution type

\begin{abstract}
ABSTRAK
Penelitian ini bertujuan untuk mengetahui pengaruh jenis larutan osmotik pada invigorasi benih kakao dengan beberapa lama pengeringan. Penelitian ini dilaksanakan di Laboratorium Teknologi Benih Fakultas Pertanian Universitas Sumatera Utara, pada bulan Agustus sampai September 2016, menggunakan rancangan acak kelompok dengan 2 faktor perlakuan. Faktor pertama adalah jenis larutan yaitu tanpa perendaman ; aquades ; air kelapa $50 \%$; air kelapa 100 $\%$; PEG $60005 \%$; PEG $600010 \%$ dan faktor kedua lama pengeringan dengan 4 taraf yaitu 1 hari; 2 hari ; 3 hari ; 4 hari. Hasil penelitian menunjukkan perlakuan jenis larutan osmotik terbaik terdapat pada perlakuan air kelapa konsentrasi 50\% yang menghasilkan laju perkecambahan sebesar 5,51 hari dan indeks vigor 3,79. Perlakuan lama pengeringan terbaik terdapat pada 1 hari pengeringan dengan rataan potensi perkecambahan 99,17\%, laju perkecambahan 4,46 hari, kecambah normal 93,06\%, kecambah abnormal, 12,21\%, benih mati 5,35\% dan indeks vigor 5,34. Interaksi perlakuan terbaik pada kombinasi perlakuan jenis larutan osmotik PEG $60005 \%$ dengan lama pengeringan 1 hari menghasilkan indeks vigor sebesar 6,80.
\end{abstract}

Kata kunci : benih kakao, invigorasi, jenis larutan osmotik, lama pengeringan 


\section{PENDAHULUAN}

Kakao merupakan salah satu tanaman penyegar yang strategis untuk dikembangkan paling tidak karena dua alasan. Pertama karena komoditi ini merupakan komoditi perdagangan internasional yang memiliki nilai yang tinggi, dan Indonesia merupakan produsen kakao terbesar ketiga di dunia. Kedua, kegiatan usaha ini 95\% melibatkan petani kecil dengan tingkat kepemilikan lahan antara 0,5 ha -2 ha. Dengan demikian perkembangan usaha kakao ini secara langsung atau tidak langsung akan berpengaruh terhadap ekonomi kerakyatan (Murwito dan Mulyani, 2013).

Salah satu faktor penentu keberhasilan pengembangan kakao adalah adanya dukungan ketersediaan benih bermutu dari varietas unggul yang sampai saat ini masih menjadi kendala dalam pengembangan kakao. Masa simpan benih dan entres kakao yang sangat terbatas menjadi salah satu hambatan dalam proses distribusi bahan tanam kakao kedaerah-daerah sentra pengembangan (Warta Penelitian dan Pengembangan Tanaman Industri, 2013).

Biji kakao merupakan biji rekalsitran akan mudah kehilangan daya kecambah setelah dikeluarkan dari buah. Agar daya hidup tetap dapat dipertahankan, cara yang paling mudah adalah tetap menempatkan biji didalam buahnya tetapi kemungkinan terserang penyakit lebih besar seperti biji yang berjamur. Disamping itu penyimpanan biji kakao yang berada didalam pod buahnya dapat menurunkan viabilitasnya setelah 15 hari penyimpanan (Saajah and Maalekuu, 2014).

Hasil penelitian Budiarti (1999) juga menunjukkan bahwa, penurunan kadar air benih kakao hingga $21 \%-23 \%$ belum menurunkan viabilitas potensialnya, namun vigornya telah menurun pada kadar air sekitar $25 \%$. Kemunduran benih kakao terjadi pada kadar air kurang dari $21 \%$ dan pada kadar air $14-15 \%$ viabilitasnya sudah sangat rendah.

Untuk mengatasi kemunduran benih telah banyak dilakukan yaitu dengan cara invigorasi. Invigorasi adalah suatu tindakan atau perlakuan untuk memulihkan atau meningkatkan vigor benih yang telah mengalami kemunduran setelah fase masak fisiologis, atau suatu cara untuk memperbaiki kondisi benih yang telah menurun viabilitasnya (Mandasari et al., 2014).

Invigorasi merupakan salah satu alternatif untuk mengatasi mutu benih yang rendah dengan cara memperlakukan benih sebelum ditanam. Digunakannya PEG dalam invigorasi dikarenakan senyawa tersebut tidak bersifat toksik dan dapat menurunkan potensial osmotik sehingga membantu imbibisi air ke dalam benih (Ailah, 2011). Berdasarkan hasil penelitian Susanti (2014) penggunaan PEG 6000 juga efektif untuk meningkatkan persentase daya berkecambah, persentase keserempakan tumbuh dan kadar air kecambah benih kenaf.

Selain dengan menggunakan PEG, invigorasi benih yang mengalami kemunduran juga dapat dilakukan dengan menggunakan bahan organik yang mengandung zat pengatur tumbuh seperti air kelapa yang diketahui banyak mengandung mineral, sitokinin, auksin, giberelin, fosfor dan kinetin yang berfungsi mempergiat pembelahan sel serta pertumbuhan tunas dan akar. Hasil penelitian Halimursyadah et al., (2015) bahan ekstrak organik priming terbaik adalah air kelapa yang dapat meningkatkan nilai potensi tumbuh dan waktu yang dibutuhkan untuk mencapai $50 \%$ perkecambahan pada benih cabai merah kadaluarsa.

Pada umumnya belum diketahui secara pasti berapa lama waktu pengeringan yang masih ditoleransi oleh benih kakao setelah dikeluarkan dari buahnya untuk disemai dilapangan dan jenis larutan osmotik yang dapat meningkatkan vigor benih yang mengalami kemunduran. Oleh karena itu penulis tertarik untuk meneliti pengaruh jenis larutan osmotik pada invigorasi benih kakao dengan beberapa lama pengeringan.

\section{BAHAN DAN METODE}

Penelitian ini dilaksanakan di Laboratorium Teknologi Benih Fakultas 
Pertanian Universitas Sumatera Utara, Medan dengan ketinggian tempat $\pm 32 \mathrm{~m}$ dpl pada bulan Agustus sampai September 2016. 6000, aquades, fungisida Delsene MX-80 WP, abu gosok, pasir dan air.

Alat yang digunakan adalah timbangan analitik, oven, bak kecambah, erlenmeyer, pisau, penggaris, ayakan, handsprayer, dan alat pendukung lainnya.

Percobaan ini menggunakan Rancangan Acak Kelompok (RAK) Faktorial dengan 2 faktor. Faktor I yaitu jenis larutan osmotik (L) yang terdiri dari: Lo : Tanpa perendaman; $\mathrm{L}_{1}$ : Air aquades selama $12 \mathrm{jam}$; $\mathrm{L}_{2}$ : Air kelapa 50\% selama 12 jam; L3 : Air kelapa $100 \%$ selama 12 jam ; L4 : Larutan PEG 5\% selama 12 jam; L5 : Larutan PEG $10 \%$ selama 12 jam. Faktor II yaitu lama pengeringan (P) yang terdiri dari 4 taraf yaitu: $\mathrm{P}_{1}$ : Pengeringan 1 hari; $\mathrm{P}_{2}$ : Pengeringan 2 hari; $\mathrm{P}_{3}$ : Pengeringan 3 hari; $\mathrm{P}_{4}$ : Pengeringan 4 hari. Sehingga diperoleh sebanyak 24 kombinasi perlakuan dengan jumlah ulangan 3. Setiap perlakuan terdapat 20 benih sehingga total seluruh benih adalah 1440.Variabel pengamatan yang diamati terdiri atas : Potensi perkecambahan (\%), laju perkecambahan (hari), kecambah normal (\%), kecambah abnormal (\%), benih mati (\%) dan Tabel 1. Potensi perkecambahan benih pengeringan

\begin{tabular}{lccccc}
\hline \multirow{2}{*}{\multicolumn{1}{c}{ Larutan Osmotik }} & \multicolumn{5}{c}{ Lama Pengeringan } \\
\cline { 2 - 5 } & P1 & P2 & P3 & P4 & Rataan \\
& (1 Hari) & $(2$ Hari) & $(3$ Hari) & (4 Hari) \\
\hline L0(Tanpa Perendaman) & 100,00 & 100,00 & 71,67 & 35,00 & 76,67 \\
L1(Aquades) & 95,00 & 98,33 & 70,00 & 35,00 & 74,58 \\
L2(Air Kelapa 50\%) & 100,00 & 100,00 & 78,33 & 28,33 & 76,67 \\
L3(Air Kelapa 100\%) & 100,00 & 100,00 & 88,33 & 26,67 & 78,75 \\
L4(5\%PEG 6000) & 100,00 & 100,00 & 68,33 & 20,00 & 72,08 \\
L5(10\%PEG 6000) & 100,00 & 98,33 & 80,00 & 11,67 & 72,50 \\
\hline \multicolumn{1}{c}{ Rataan } & 99,17 a & 99,44 a & $76,11 \mathrm{~b}$ & $26,11 \mathrm{c}$ &
\end{tabular}

Keterangan : Angka-angka yang diikuti notasi yang sama menunjukkan berbeda tidak nyata menurut Uji Jarak Berganda Duncan pada taraf $\alpha=0,05$.

Potensi perkecambahan benih pada perlakuan jenis larutan dengan lama pengeringan dapat dilihat pada Tabel 1 .
Bahan yang digunakan adalah buah kakao, air kelapa, polyethylene glikol (PEG)

indeks vigor. Data yang diperoleh dianalisis menggunakan analisis sidik ragam. Jika perlakuan berpengaruh nyata berdasarkan analisis sidik ragam dilanjutkan dengan uji beda rataan menggunakan Uji Jarak Berganda Duncan (DMRT) pada taraf 5\%.

Tahapan pelaksanaan penelitian dimulai dari persiapan benih dan buah kelapa, pembersihan pulp dan pemberian fungisida pada benih, aplikasi perlakuan pengeringan benih, pengukuran kadar air benih setelah perlakuan pengeringan, perlakuan perendaman benih, persiapan media perkecambahan, penanaman, dan pemeliharaan.

\section{HASIL DAN PEMBAHASAN}

Berdasarkan pengamatan kadar air dihasilkan kadar air benih tanpa pengeringan, pengeringan 1 hari, pengeringan 2 hari, pengeringan 3 hari dan pengeringan 4 hari secara berturut yaitu, $35,6 \%, 18,8 \%, 16,9 \%$, $10,4 \%$ dan $8,84 \%$ yang mengalami penurunan dari hari ke-0 sampai ke-4.

(\%) pada perlakuan jenis larutan dengan lama Potensi perkecambahan benih tertinggi terdapat pada perlakuan P2 sebesar 99,44\% tetapi tidak berbeda nyata dengan $\mathrm{P} 1$ dan berbeda nyata dengan perlakuan lainnya. Potensi perkecambahan terendah terdapat pada perlakuan $\mathrm{P} 4$ sebesar $26,11 \%$. Hal ini menunjukkan semakin lama proses 
pengeringan benih kakao dapat menyebabkan benih kehilangan kandungan air hingga menurunkan aktivitas enzim dan metabolisme di dalam benih sehingga benih sulit berkecambah bahkan mengalami kematian. Hal ini sesuai dengan hasil penelitian Vanitha et al., (2005) yang melaporkan

Tabel 2. Laju perkecambahan benih (Hari) pada perlakuan jenis larutan dengan lama pengeringan

\begin{tabular}{lccccc}
\hline \multirow{2}{*}{ Larutan Osmotik } & \multicolumn{5}{c}{ Lama Pengeringan } \\
\cline { 2 - 5 } & $\begin{array}{c}\text { P1 } \\
\text { (1 Hari) }\end{array}$ & $\begin{array}{c}\text { P2 } \\
(2 \text { Hari })\end{array}$ & $\begin{array}{c}\text { P3 } \\
(3 \text { Hari })\end{array}$ & $\begin{array}{c}\text { P4 } \\
\text { (4 Hari) }\end{array}$ \\
\hline L0(Tanpa Perendaman) & 6,65 & 6,00 & 8,43 & 9,33 & $7,60 \mathrm{~b}$ \\
L1(Aquades) & 3,95 & 5,27 & 6,02 & 7,94 & $5,80 \mathrm{a}$ \\
L2(Air Kelapa 50\%) & 4,17 & 4,10 & 5,72 & 8,11 & $5,51 \mathrm{a}$ \\
L3(Air Kelapa 100\%) & 4,52 & 3,92 & 6,17 & 8,17 & $5,69 \mathrm{a}$ \\
L4(5\%PEG 6000) & 3,35 & 4,48 & 6,13 & 9,79 & $5,94 \mathrm{a}$ \\
L5(10\%PEG 6000) & 4,15 & 4,29 & 4,76 & 8,83 & $5,52 \mathrm{a}$ \\
\hline \multicolumn{1}{c}{ Rataan } & $4,46 \mathrm{a}$ & $4,68 \mathrm{a}$ & $6,21 \mathrm{~b}$ & $8,70 \mathrm{c}$ & \\
\hline
\end{tabular}

Keterangan : Angka-angka yang diikuti notasi yang sama pada baris yang sama dan kolom yang sama menunjukkan berbeda tidak nyata menurut Uji Jarak Berganda Duncan pada taraf $\alpha=0,05$.

bahwa setelah penyimpanan kadar air di dalam benih kakao dari $35,46 \%$ menjadi $12 \%$ dengan persentase perkecambahan pada hari pertama $91 \%$ dan mendekati $0 \%$ pada hari ke sepuluh.

Laju perkecambahan benih pada perlakuan jenis larutan dengan lama pengeringan dapat dilihat pada Tabel 2. Laju perkecambahan benih tertinggi terdapat pada perlakuan jenis larutan L2 sebesar 5,51 hari dan terendah pada perlakuan L0 sebesar 7,60 hari. Laju perkecambahan benih tertinggi terdapat pada perlakuan lama pengeringan P1 sebesar 4,46 hari dan terendah terdapat pada perlakuan lama pengeringan $\mathrm{P} 4$ sebesar 8,70 hari dan berbeda nyata dengan perlakuan lainnya. Hal ini dikarenakan air kelapa merupakan salah satu perangsang tumbuh alami yang mengandung hormon seperti sitokinin, auksin dan giberelin yang sangat dibutuhkan pada proses perkecambahan. Hal ini sesuai dengan pernyataan Sujarwati et al., (2011) pada hasil penelitian penggunaan air kelapa untuk meningkatkan perkecambahan dan pertumbuhan palem putri pada berbagai konsentrasi air kelapa menunjukkan hasil yang berpengaruh nyata. Hal ini juga didukung oleh Marpaung dan Hutabarat (2015) pada penelitian jenis perangsang tumbuh dan bahan asal stek pada pertumbuhan bibit tin dengan jenis bahan alami air kelapa $50 \%$ selama 12 jam menghasilkan waktu bertunas lebih cepat, panjang tunas, jumlah daun, panjang dan bobot basah akar yang tinggi. Bahan alami air kelapa 50\% dapat menggantikan perangsang akar sintetis sebagai ZPT.

Persentase kecambahan normal pada perlakuan jenis larutan dengan lama pengeringan dapat dilihat pada Tabel 3 . Persentase kecambah normal tertinggi terdapat pada perlakuan P1 sebesar 93,06\% yang tidak berbeda nyata dengan perlakuan P2 tetapi berbeda nyata dengan perlakuan lainnya dan terendah terdapat pada perlakuan $\quad \mathrm{P} 4 \quad$ sebesar $8,33 \%$. 
Tabel 3. Persentase kecambahan normal (\%) pada perlakuan jenis larutan dengan lama pengeringan

Lama Pengeringan

Larutan Osmotik

P2 P3

P3

(2 Hari)

(3 Hari)

95,00

38,33

90,00

45,00

5,00

Rataan

L1(Aquades)

80,00

90,00

58,33

20,00

56,25

L2(Air Kelapa 50\%)

L3(Air Kelapa 100\%)

96,67

98,33

55,00

10,00

58,75

L4(5\%PEG 6000)

98,33

91,67

51,67

8,33

63,75

L5(10\%PEG 6000)

100,00

93,33

61,67

3,33

64,58

Rataan

93,06 a

93,06 a

$51,67 \mathrm{~b}$

3,33

61,25

64,58

Keterangan : Angka-angka yang diikuti notasi yang sama menunjukkan berbeda tidak nyata menurut Uji Jarak Berganda Duncan pada taraf $\alpha=0,05$.

Tabel 4. Persentase kecambah abnormal (\%) pada perlakuan jenis larutan dengan lama pengeringan

Lama Pengeringan

\begin{tabular}{lccccc}
\cline { 2 - 4 } \multicolumn{1}{c}{ Larutan Osmotik } & P1 & P2 & P3 & Rataan \\
& $(1$ Hari $)$ & $(2$ Hari $)$ & $(3$ Hari $)$ & $(4$ Hari $)$ & \\
\hline L0(Tanpa Perendaman) & 13,33 & 5,00 & 33,33 & 30,00 & 20,42 \\
L1(Aquades) & 15,00 & 8,33 & 25,00 & 15,00 & 15,83 \\
L2(Air Kelapa 50\%) & 3,33 & 10,00 & 20,00 & 18,33 & 12,92 \\
L3(Air Kelapa 100\%) & 3,33 & 1,67 & 33,33 & 18,33 & 14,17 \\
L4(5\%PEG 6000) & 1,67 & 8,33 & 16,67 & 16,67 & 10,84 \\
L5(10\%PEG 6000) & 0,00 & 5,00 & 18,33 & 8,33 & 7,92 \\
\hline \multicolumn{1}{c}{ Rataan } & $6,11 \mathrm{~b}$ & $6,39 \mathrm{~b}$ & $24,44 \mathrm{a}$ & $17,78 \mathrm{a}$ & \\
\hline
\end{tabular}

Keterangan : Angka-angka yang diikuti notasi yang sama menunjukkan berbeda tidak nyata menurut Uji Jarak Berganda Duncan pada taraf $\alpha=0,05$.

Dari hasil penelitian menunjukkan semakin lama hari pengeringan menghasilkan kecambah normal yang sedikit. Hal ini disebabkan oleh semakin menurunnya metabolisme di dalam benih dengan berkurangnya cadangan makanan dan kadar air. Hal ini sesuai dengan pernyataan (Budiarti, 1999) bahwa penurunan kadar air pada benih rekalsitran berkolerasi dengan tingkat viabilitas benih, pada saat pengeringan akan terjadi kerusakan seluler seperti kebocoran membran dan penurunan metabolisme sel.

Persentase kecambah abnormal pada perlakuan jenis larutan dengan lama pengeringan dapat dilihat pada Tabel 4 . Persentase kecambah abnormal tertinggi terdapat pada perlakuan P3 sebesar 24,44\% yang berbeda tidak nyata dengan P2 tetapi berbeda nyata dengan perlakuan lainnya dan terendah terdapat pada perlakuan P1 sebesar $6,11 \%$. Hal disebabkan oleh menurunnya viabilitas benih selama proses pengeringan sehingga menghasilkan kecambah normal semakin tinggi sejak pengeringan 1 sampai 4 hari. Hal ini sesuai dengan pernyataan (Budiarti, 1999) bahwa penurunan kadar air pada benih rekalsitran berkolerasi dengan tingkat viabilitas benih, pada saat pengeringan akan terjadi kerusakan seluler seperti kebocoran membran dan penurunan metabolisme sel. Berbeda dengan benih ortodoks, bahkan penurunan kadar air benih dapat meningkatkan daya simpan dan ketika imbibisi pada saat perkecambahan tidak merusak struktur protein.

Persentase benih mati tertinggi terdapat pada perlakuan P4 sebesar 73,89\% yang berbeda nyata dengan perlakuan lainnya dan terendah terdapat pada perlakuan P2 sebesar $0,56 \%$. Pengeringan benih kakao sampai 4 hari berturut-turut dapat mempertinggi respirasi pada benih sehingga benih banyak kehilangan air yang dapat 
Tabel 5. Persentase benih mati (\%) pada perlakuan jenis larutan dengan lama pengeringan

\begin{tabular}{|c|c|c|c|c|c|}
\hline \multirow[b]{2}{*}{ Larutan Osmotik } & \multicolumn{4}{|c|}{ Lama Pengeringan } & \multirow[b]{2}{*}{ Rataan } \\
\hline & $\begin{array}{c}\text { P1 } \\
\text { (1 Hari) }\end{array}$ & $\begin{array}{c}\text { P2 } \\
\text { (2 Hari) }\end{array}$ & $\begin{array}{c}\text { P3 } \\
\text { (3 Hari) }\end{array}$ & $\begin{array}{c}\text { P4 } \\
\text { (4 Hari) }\end{array}$ & \\
\hline L0(Tanpa Perendaman) & 0,00 & 0,00 & 28,33 & 65,00 & 23,33 \\
\hline L1(Aquades) & 5,00 & 1,67 & 30,00 & 65,00 & 25,42 \\
\hline L2(Air Kelapa 50\%) & 0,00 & 0,00 & 21,67 & 71,67 & 23,33 \\
\hline L3(Air Kelapa 100\%) & 0,00 & 0,00 & 11,67 & 73,33 & 21,25 \\
\hline L4(5\%PEG 6000) & 0,00 & 0,00 & 31,67 & 80,00 & 27,92 \\
\hline L5(10\%PEG 6000) & 0,00 & 1,67 & 20,00 & 88,33 & 27,50 \\
\hline
\end{tabular}

Keterangan : Angka-angka yang diikuti notasi yang sama menunjukkan berbeda tidak nyata menurut Uji Jarak Berganda Duncan pada taraf $\alpha=0,05$.

Tabel 6. Indeks vigor benih pada perlakuan jenis larutan dengan lama pengeringan

\begin{tabular}{|c|c|c|c|c|c|}
\hline \multirow[b]{2}{*}{ Larutan Osmotik } & \multicolumn{4}{|c|}{ Lama Pengeringan } & \multirow[b]{2}{*}{ Rataan } \\
\hline & $\begin{array}{c}\text { P1 } \\
\text { (1 Hari) }\end{array}$ & $\begin{array}{c}\mathrm{P} 2 \\
\text { (2 Hari) }\end{array}$ & $\begin{array}{c}\text { P3 } \\
\text { (3 Hari) }\end{array}$ & $\begin{array}{c}\text { P4 } \\
\text { (4 Hari) }\end{array}$ & \\
\hline L0(Tanpa Perendaman) & 3,27 ef & 3,61 ef & $1,78 \mathrm{gh}$ & $0,8 \mathrm{~h}$ & $2,37 \mathrm{~b}$ \\
\hline L1(Aquades) & 5,43 abc & 4,17 cde & $2,53 \mathrm{fg}$ & $0,94 \mathrm{~h}$ & 3,27 a \\
\hline L2(Air Kelapa 50\%) & $5,71 \mathrm{ab}$ & $5,47 \mathrm{abc}$ & 3,18 efg & $0,79 \mathrm{~h}$ & 3,79 a \\
\hline L3(Air Kelapa 100\%) & 5,21 bc & $5,75 \mathrm{abc}$ & 3,16 efg & $0,7 \mathrm{~h}$ & 3,71 a \\
\hline L4(5\%PEG 6000) & 6,8 a & $5,02 \mathrm{bcd}$ & $2,54 \mathrm{fg}$ & $0,52 \mathrm{~h}$ & 3,72 a \\
\hline L5(10\%PEG 6000) & $5,59 \mathrm{abc}$ & 5,12 bcd & 3,68 def & $0,33 \mathrm{~h}$ & 3,68 a \\
\hline Rataan & 5,34 a & $4,86 \mathrm{a}$ & $2,81 \mathrm{~b}$ & $0,68 \mathrm{c}$ & \\
\hline
\end{tabular}

Keterangan : Angka-angka yang diikuti notasi yang sama pada baris, kolom dan kombinasi keduanya menunjukkan berbeda tidak nyata menurut Uji Jarak Berganda Duncan pada taraf $\alpha=0,05$.

merusak enzim akibatnya enzim tidak dapat aktif dan menipisnya cadangan makanan di dalam benih sehingga tidak ada energi yang tersimpan untuk melakukan pembelahan sel. Hal ini sesuai dengan pernyataan Ross (1986) yang mengemukakan penyebab benih kehilangan kemampuan berkecambah yaitu berkurangnya cadangan makanan tersedia tetapi metabolismenya terbatas, perubahan komposisi kimia benih sehingga cadangan energi berkurang untuk perkecambahan dan kerusakan genetik yaitu terjadi mutasi pada benih yang mundur dengan menurunnya kemampuan benih untuk mengganda, membelah dan tumbuh.

Indeks vigor benih pada perlakuan jenis larutan dengan lama pengeringan dapat dilihat pada Tabel 6. Indeks vigor benih yang tertinggi terdapat pada interaksi perlakuan L4P1 sebesar 6,80 tetapi berbeda tidak nyata dengan interaksi perlakuan L2P1, L1P1,
L5P1, L3P2 dan L2P2 dan berbeda nyata dengan interaksi perlakuan lainnya dan terendah terdapat pada interaksi perlakuan L5P4 sebesar 0,33 tetapi berbeda tidak nyata dengan interaksi perlakuan L4P4, L3P4, L2P4, L1P4, L0P4 dan L0P3 dan berbeda nyata dengan interaksi perlakuan lainnya. Pada pengeringan 1 hari benih masih menunjukkan vigoritasnya dengan direndam pada berbagai jenis larutan, tetapi jika dikeringkan selama 4 hari benih sudah mengalami penurunan kadar air yang tajam sehingga jika diberi perlakuan perendam dengan berbagai jenis larutan menunjukkan hasil yang berbeda tidak nyata dengan tanpa direndam.

Peristiwa diatas disebabkan oleh benih kakao yang merupakan benih rekalsitran yang sangat peka terhadap pengeringan dan cepat mengalami kemunduran pada kadar air dan suhu yang rendah. Hal ini sesuai dengan hasil 
penelitian Vanita et al., (2005) bahwa 1-10 hari setelah penyimpanan kadar air di dalam benih kakao dari $35,46 \%$ menjadi $12 \%$ dengan persentase perkecambahan pada hari pertama sebesar $91 \%$ dan mendekati $0 \%$ pada hari ke 10.

Peningkatan konsentrasi air kelapa menjadi $100 \%$ dan PEG-6000 menjadi 10\% dapat menghambat penyerapan air kedalam benih. Menurut Nurmauli dan Nurmiaty (2010) hal ini dikarenakan konsentrasi yang tinggi pada larutan mengakibatkan nilai potensial osmotik disekitar benih menjadi semakin negatif, sehingga air sulit diserap oleh benih. Rendahnya nilai potensial osmotik larutan dapat menghambat proses imbibisi pada fase I, sehingga menyebabkan proses metabolisme pada fase II ikut terhambat. Akibatnya, nutrisi dan energi yang dihasilkan untuk perkecambahan menjadi lebih sedikit dan pembentukan struktur baru ikut terhambat.

\section{SIMPULAN}

Perlakuan invigorasi benih kakao dengan berbagai jenis larutan pada beberapa lama pengeringan nyata meningkatkan laju perkecambahan dan indeks vigor benih. Jenis larutan terbaik terdapat pada perlakuan jenis larutan air kelapa 50\% yang menghasilkan laju perkecambahan 5,51 hari dan index vigor benih sebesar 3,79. Lama pengeringan terbaik terdapat pada perlakuan pengeringan 1 hari dengan menghasilkan potensi perkecambahan sebesar $99,17 \%$ laju perkecambahan 4,46, kecambah normal 93,06 \%, kecambah abnormal $6,11 \%$ dan benih mati sebesar $0,83 \%$. Interaksi perlakuan jenis larutan dengan lama pengeringan terbaik terdapat pada perlakuan PEG $60005 \%$ x pengeringan 1 hari yang menghasilkan index vigor benih sebesar 6,80 .

\section{DAFTAR PUSTAKA}

Ailah, M. H. 2011. Pengaruh Konsentrasi Dan Lama Perendaman Menggunakan Polyethylene Glicol (PEG) 6000 Terhadap Viabilitas Benih Jarak Pagar
(Jatrophacurcas L.). Fakultas Sains Dan Teknologi Universitas Islam Negeri (Uin) Maulana Malik Ibrahim. Malang.

Budiarti, Y. 1999. Konservasi Vigor Benih Rekalsitran Kakao (Theobroma cacao L.) dengan Penurunan Kadar Air dan Proses Invigorasinya. Institute Pertanian Bogor. Bogor.

Halimursyadah., Jumini., dan Muthiah. 2015. Penggunaan Organic Priming dan Periode Inkubasi Untuk Invigorasi Benih Cabai Merah (Capsicum annum L.) Kadaluarsa Pada Stadia Perkecambahan. Program Studi Agroteknologi Fakultas Pertanian Universitas Syiah Kuala. Aceh. J.Floratek 10(2):78-86.

Mandasari, P., Fathurrahman, dan Baharudin, 2014. Invigorasi Benih Nangka (Artocarpus heterophyllus Lamk) Setelah Periode Simpan dengan Pemberian ZPT. Program Studi Agroteknologi Fakultas Pertanian Universitas Tadulako, Palu. e-J. Agrotekbis 2 (2) : 155-160.

Marpaung, A.E dan R.C. Hutabarat. 2015. Respons Jenis Perangsang Tumbuh Berbahan Alami dan Asal Setek Batang Terhadap Pertumbuhan Bibit Tin (Ficus carica L.). Balai Penelitian Tanaman Sayuran. Bandung. J. Hort. 25(1): 37-43.

Murwito, S., dan S. Mulyati. 2013. Kebutuhan Pengembangan Usaha Kakao dengan Pendekatan Rantai Nilai. Ford Foundation dan Komite Pemantauan Pelaksanaan Otonomi Daerah. Jakarta.

Nurmauli., dan Y. Nurmiaty. 2010. Studi Metode Invigorasi pada Viabilitas Dua Lot Benih Kedelai yang Telah Disimpan Selama Sembilan Bulan. Jurnal Ilmu Pertanian Indonesia. 15(1):20-24.

Ross, E.E. 1986. Precepts of succesful seed storage, pp. 1-26. In M.B. McDonald, Jr and C.J Nelson (Eds). Physiology of Seed Deterioration. CSSA Special ubl. Number 11 Madison, Wisconsin. 
Saajah, B.K., and B.K. Maalekuu. 2014. Determination of Postharvest Pod Storage on Viability and Seedling Growth Performance of Cocoa (Theobroma cacao L.) in the Nursery. Canadian Center of Science and Education. Ghana.Vol.6, No.4.

Sujarwati., S. Fathonah., E. Johani dan Herlina. 2011. Penggunaan Air Kelapa untuk Meningkatkan Perkecambahan dan Pertumbuhan Palem Putri (Veitchia merilli). Jurnal Sagu. 10(1): 24-28.

Susanti, E. 2014. Pengaruh Osmoconditioning dengan PEG (Polyethylene Glycol) 6000 Terhadap Viabilitas Benih Kenaf (Hibiscus cannabinus L.). Fakultas Sains dan Teknologi- Universitas Islam Negeri Maulana Malik Ibrahim. Malang.

Vanitha, C., K. Ramamoorthy., A. Vijayakumar., and K.Sivasubramaniam. 2005. Moist Sand Conditioning to Minimize Loss of Viability in Cocoa (Theobroma cacao Linn.) Seed. Agricultural College and Research Institute, Madurai-625 104, Tamil Nadu. India.

Warta Penelitian dan Pengembangan Tanaman Industri. 2013. Teknis Pembangunan Kebun Benih Sumber Kakao. Balittri. Jakarta. 19(1):27-28. 
4725

Vol.5, No.1. April 2018. (17) : 128- 135 